\title{
Future of Policing in the UK: Understanding the Economics
}

\author{
Colin Rogers ${ }^{1} \&$ James Gravelle ${ }^{1}$ \\ ${ }^{1}$ Centre for Police Sciences, University of Glamorgan, Wales, UK \\ Correspondence: James Gravelle, Centre for Police Sciences, University of Glamorgan, Wales, UK, CF37 1AT. \\ Tel: 44-1443-482-593. E-mail: jgravell@glam.ac.uk
}

Received: November 1, 2012 Accepted: February 20, 2013 Online Published: February 26, 2013

doi:10.5539/res.v5n1p116

URL: http://dx.doi.org/10.5539/res.v5n1p116

\begin{abstract}
Policing does not exist in a social, political or economic vacuum. The economic framework in which policing must operate is constantly changing and is becoming increasingly difficult to predict. This fluid and dynamic financial situation combined with societal and political pressures make the task of policing even more complex. This paper examines the possible impact of contracting budgets and increasing demand from the public will have on the delivery of policing products and services. The article considers the role the private sector may have in delivering such policing products to the public along with alternative funding mechanisms such as payments by results. Such reforms are unquestionably significant and will change the relationship between police service and the public. Issues such as accountability, efficiency and overall economic viability are explored in relation to some of the possible reforms facing policing with the UK.
\end{abstract}

Keywords: police reform, accountability, customers, privatisation, outsourcing, payment by results

\section{Introduction}

Policing in any country does not exist in a social, political or economic vacuum (Dölling, 1993) and it is clear that pressure on policing is set to continue as the cycle of reform builds up momentum. Recent reforms in policing have been significant, changing the dynamic landscape in which it operates. Reforms to police officer pay and conditions, the introduction of police and crime commissioners along with contracting budgets within the UK mas made for an interesting and fascinating combination that is clearly having an impact on the delivery of police services (Audit Commission, 2010; Winsor, 2012; Rogers \& Gravelle, 2012). The challenge for the public police under such pressure is of course is to maintain the quality of products and services delivered to the public, however difficult this may prove (Home Office, 2010b; Home Office, 2010c; Gravelle \& Rogers, 2011). The purpose of this article is to consider the major elements and fundamentals currently underpinning the proposed changes and reform. In particular, the article will consider several areas associated with the recent announcement about outsourcing and payments by results (PBR) along with some thoughts on the future of policing, some of which may be contentious, which it is hoped will stimulate and contribute to the ongoing debate about the future of policing in England and Wales.

\section{Outsourcing}

The recent announcement by some police forces that they are seeking to outsource activities that do not require warranted officers to private companies has come as a shock to the media, the general public and others interested in policing within this country (Blair, 2012). It has prompted the Home Office and senior police officers to support this action by reinforcing the fact that they are determined to do anything that will help the police to become more effective and better able to fight crime (Travis \& Jowit, 2012). Indeed, the terminology 'to fight crime' seems quite prominent in government rhetoric that illustrates perhaps a narrow and naive understanding of the subtle relationship between the police and the communities they serve.

Cleary there is a need for economic restructuring regarding the way in which police deliver their services if economy, efficiency and effectiveness are to be achieved in such a dire economic framework. The recent publication of Winsor report part 2 with all its recommendations shows how prominent this will be in forthcoming debates about policing in this country (Winsor, 2012). However, for some, the idea of allowing private security companies to perform many functions now carried out by sworn officers is a matter for great concern (Jones \& Newburn, 2006). Once we strip away the simple idea that the police service in this country is seen by many as a shining example of how to police developed countries, with the phrase 'best police in the world' often used to describe the model employed here, there are other points that need to be discussed and debated (Neyroud, 2010). 
The recent proposals by some police services to outsource policing services, on behalf of many other forces, suggest that private companies could take responsibility for investigating crimes, patrolling neighbourhoods and even detaining suspects as part of a radical outsourcing package. The contract, it is alleged has a potential value of $£ 1.5$ billion over seven years, rising to a possible $£ 3.5$ billion depending on how many forces get involved (Travis \& Williams, 2012). The programme has the potential to become the main vehicle for outsourcing police services and has been supported by such individuals as Sir Ian Blair who believes this will allow chief officers to be able to deliver a more focused police service utilising its sworn officers for maximum effect (Blair, 2012). Given that there has been a forceful drive for change and restructuring of police services in this country as witnessed by reports from ACPO and HMIC, and also the Winsor report which has announced among its recommendations changes in pay and structure, there should really be no surprise at what is an extension of the private sector provisions already in place (Button, 2002; Winsor, 2012; Home Office, 2010a, 2012b; HMIC, 2010). However, there are several important areas where questions need to be asked, issues need to be debated and the context for change discussed.

\section{Advantages of Outsourcing}

In periods of rapid growth with spending on public sector services increasing exponentially over recent years, back office functions have inevitably expanded (Gravelle \& Rogers, 2010). This expansion of back office and supportive functions, if left unchecked, may begin to consume valuable resources, both human and financial, at the expense of core functions (Savage, 2007). This misalignment may in the long run prove detrimental to the organisations ability to remain effective in markets that are becoming increasingly competitive. Outsourcing such activities may allow for a refocusing or re-alignment of priorities on core business activities that are important to the customer without sacrificing the valuable and essential quality of service provided by back office functions (Mcivor, 2005).

The cost and efficiency savings of any such outsourcing must also be acknowledged. It is difficult for organisations to have the expertise of being able to deliver high quality products in their specific areas, whilst also being experts at delivering supportive functions that are often complicated, technical and labour intensive in nature (Erridge et al., 2001). Outsourcing such activities to vendors that specialise in their particular field who have the specialist equipment, skills and resources necessary may enable tasks to be completed faster, cheaper and ultimately of course delivered with better quality.

Intertwined with efficiency and economic viability is resilience. Outsourcing appears to offer a greater risk sharing potential along with reduced overheads essential to any organisation or company (Hunter \& Saunders, 2007). Outsourcing vendors are often specialists at assessing risk, allowing a fixable staffing approach in dealing with seasonal, cyclical changes in demand. It is difficult for some organisations to change their staffing levels quickly, however, distributing risk across many outsourcing vendors may allow this effect to be mitigated and resilience to be built into the business model. Periods of high employee turnover will add uncertainty and inconsistency and this should be carefully considered. Although these advantages may give increasing operational control for departments that have been poorly managed and have spiralling costs that have become a burden on organisation effectives, there are of course many disadvantages that must be considered as part of any consolation exercise or risk analysis into the possibilities of outsourcing (Brogden \&Ellison, 2012).

\section{Payment by Results}

Payment by results (PBR) is the funding system used for payment of work carried out by National Health Service providers in England (Audit Commission, 2011). This funding arrangement, it is alleged, offers major opportunities and incentives from which all can benefit. Its system purports to improve efficiency and cost effectiveness whilst giving the opportunity to redesign services aimed at providing services with greater fairness and transparency in how organisations are funded, whilst introducing budget discipline and financial accountability for hospitals and health provision. In conjunction with other reforms, it is alleged to support patient choice (Audit Commission, 2012a).

In terms of functionality, the PBR approach rests upon commissioning and paying for services. Commissioners pay service providers according to how well they achieve specified outcomes rather than outputs or volumes of service (Audit Commission, 2012b). These outcomes may be social, economic, financial or a combination of all three. What sets PBR apart from other contract types is that a significant amount of payment is withheld until the results are delivered. The payment is directly related to the level of success.

This approach should not really come as a surprise to those in the public services as it fits into the present governments policy for achieving 'better for less' from public services (Gravelle \& Rogers, 2011). However, it is not just in the health service that this approach is being utilised. In some public services, notably the health 
service, the use of PBRs are developing quickly and some early schemes include reducing reoffending by individuals, diverting young offenders from custodial sentences, helping the unemployed find work and preventing children from entering into care etc. This approach is clearly in line with the governments 'Open Services' legislation which states that PBR will provide a constant and tough financial incentive for providers to deliver good services throughout the term of the contract (Cabinet Office, 2012).

\subsection{Benefits of Approach}

At its best it is alleged, PBR can deliver savings and bring in new resources at a time when budgets are under great pressure (Maynard, 2012). It also defers costs to commissioners to allow time to realise the benefits of change and preventative work. It can also provide sustained incentives for providers to improve outcomes and to find new innovative ways of doing so. Further, this approach actually removes operational risk away from the commissioner, onto the provider and can provide clearer accountability for outcomes (Whitfield, 2012). In addition to these advantages, PBR offers a choice to consumers or customers in markets that have previously been dominated by one or two service providers, for example, the NHS, the police service or other public sector agencies that operate within monopolies or oligopolies. It is suggested that driving and promoting competition within closed market environments will improve outcomes for customers or in the wider and broadest context, improve outcomes for entire communities (Lowndes \& Pratchett, 2012). At its maximum competitiveness, markets would see a mixture of private, public and voluntary agencies offering products or services to customers in whom individuals have the decision and power to decide to seek a service from their preferred provider (Maynard, 2012). Overseeing the competitiveness of such markets are commissioners, who have the ultimate power to commission and decommission poorly performing providers. Such marked-based mechanisms for service delivery may deliver the improvements necessary to deliver benefits for end-users.

As noted previously, PBR was first introduced within the NHS under the Labour government in 2000, and has been adopted since then throughout other areas relating to drugs, crime, rehabilitation, children's service and welfare. Taking a recent example commissioned by the coalition government, the drugs strategy resulted in service providers being paid based on achievements of outcomes such as recipients being free of drug dependence or back in work (Home Office, 2010d). In terms of crime and rehabilitation, companies are now paid on reoffending rates of prisoners released from prisoners. For children's services, some local authorities have been exploring ways to introduce PBR by attempting to divert young offenders away from the criminal justice system or reducing the number of vulnerable children going into care.

\subsection{Problems of the Approach}

If managed incorrectly, it could lead to financial instability, difficulties with service delivery and poorer outcomes for customers. In particular there may be problems particularly with financial management, data quality and effective and innovative commissioning (Maynard, 2012).

Payment by results requires good quality data on costs and clinical activity and it has been suggested that the following are required for a successful implementation of such a scheme

- Investment in IT systems focusing upon the recording and coding of customer activity, reviewing and strengthening their financial management systems and capacity to ensure that they are equipped to manage in the new environment.

- Ensuring front line managers and staff are aware and fully understand the implications of payment by results and are committed to the changes needed to implement the new system effectively.

- Ensuring a sound monitoring framework is in place to address possible manipulation or gaming of the system.

In the long term, there is also the possibility that the comodification of public services and the introduction of a profit motive may displace other powerful drives such as commitments to public service provision, mission statement or other delivery promises. Indeed, in the past, there have been reported problems with the veracity of data used for performance measurement within the police organisation, and this must also be of some concern, especially when figures may be used to measure success.

\section{Restructuring the Model}

When one considers the wider context of policing in this country it should come as no surprise that this attempt at outsourcing should be made (Frost \& Manning, 1999). There are precedents. These include custody duties being carried out by private security firms and investigations (to a certain point) and statements being taken by private companies that consist of retired detectives etc have been with us for a number of years. Indeed, 
Lincolnshire already has a contract with G4S for outsourced work (Skinns, 2009). As forces seek to realign with vastly reduced budgets, the selling off of police stations and other capital stock and the realignment of resources to demand must surely have sent the message to all that policing will intrinsically change in this country for ever following this period of readjustment (Davis, 2010). The extension therefore seems a logical one in the context of the financial reduction police forces face. However, there are some areas that the application of this approach will impact upon.

\subsection{Commissioners}

The danger always has been that the new commissioners would be too political in their outlook, which in turn would cloud many realistic issues for the police organisation (Home Affairs Select Committee, 2010; Loveday, 1993). For example, in the framework of the recent announcements of outsourcing activities, John Prescott, who is to stand for election as commissioner for Hull, has announced he will resist this activity and base his electoral campaign upon putting 'more bobbies on the beat' (Travis, 2012). Whilst this may be an admirable electioneering announcement, what is the reality of this claim? Will the local police force be able to sustain such a claim in the face of major economic constraints? How much conflict would this generate between the chief officer of that particular force and the elected representative of the community? Clearly there could be further conflict between those elected by the people and those charged with trying to deliver a police service with a vastly reduced operating budget.

\subsection{American Model}

When one considers the proposed methods of change currently happening within the police service in the UK, one can only come to the conclusion that it is to the American model that we seem to be leaning. Political positions similar to the police and crime commissioner are a dominant feature of the American model, as is the multi layered approach to policing including federal, national, state and local police forces working alongside private security/police agencies (Gravelle \& Rogers, 2011). We already have to some extent a multi layered police function in this country, as evidenced by the National Crime Agency, regional collaboration, force-level and even different types of personnel performing the police function, namely warranted police officers and community support officers, not to mention volunteers of all sorts of variety (Rogers \& Lewis, 2007; Williamson, 2008). Slowly we seem to be adopting this model which should contribute to the discussion surrounding the accountability of our police.

\section{The Problem of Accountability}

Just as the police hold citizens to account for their behaviour when they break the law, we expect the police to have the same standards and more (Garland, 2001). We expect them to not only enforce the laws of the land but to be of the highest ethical standard. Hence the need for a robust accountability process for the police (Flanagan, 2008; Halpern, 2007). This refers, in truth, to efforts to control police behaviour, and always has been a problem for police administrators (Ianni \& Ianni, 1983). There are two main kinds of accountability, namely external such as the IPCC, the current tri-partite arrangement involving the Home Office, Chief Officers and the Police Authorities as well as civil litigation and of course the criminal law itself (Markham \& Punch, 2007). Internal accountability involves personal accountability, the chain of command, policies and procedures and of course complaints procedures. This illustrates how serious we take accountability of the police. However, outsourced agencies may not have the same robust accountability procedures as those in place for publically funded police agencies (Bryett \& Lewis, 1994). The fundamental point of the police organisation is to provide a service; the underlying fundamental of private business is, in the main, to make a profit for its executives or shareholders (Kendell, 2011). The question then needs to be asked how can these can be reconciled without specific legislation put in place to ensure proper and correct accountability? At present, the IPCC, (Independent Police Complaints Commission) the external accountability agent for the police, is available for people to ensure their complaints get a hearing against police officers (National Audit Office, 2008). What channels would be available for complaints against private security companies, who are currently accountable in the main through a voluntary code of conduct?

\section{The Problem of Visibility}

The police in England and Wales were introduced as a visible deterrent to crime and disorder (Klockars, 1985). This was achieved by high visibility and surveillance through patrol. Whatever the different historians' viewpoint, be it traditional or revisionist, it is to the credit of the ordinary police officers that they have become regarded as a fact of everyday life in the UK. Their presence is to the majority of people a reassurance, despite the fact they have enormous power and in fact represent the status in power and authority within our society (Hughes, 2007). In short they serve a purpose for most of society by their presence and the iconography of the 
'bobby on the beat' must not be underestimated in terms of support for and confidence in the police organisation. It would appear therefore that this is the most contentious issue, and the most unpalatable part of the proposals for outsourcing. Would the public be happy for security firms to engage in vehicle and foot patrol in their communities rather than fully warranted police officers who have the power to arrest and deal with miscreants with all the force that the office of constable holds in this country? Would senior officers be tempted to deploy such resources in busy times or at times when very serious incidents swallow up warranted officers? Despite these valid concerns, there is the presupposition that the public would prefer warranted officers, when clearly the introduction of Community Support Officers seems to have been readily accepted in the main (Home Office, 2008). However, there is a difference when it comes to Community Support Officers and private security patrols, and that is accountability within a democratic policing model as discussed. At least Community Support Officers are accountable to the Chief Officer of police where they work, unlike private security agencies at present.

\section{Self Inflicted?}

Another viewpoint which is worthy of discussion is that the police organisation in England and Wales may have brought about these changes upon themselves. Notwithstanding the current economic climate which is actually forcing senior officers to contemplate otherwise unthinkable approaches to delivering a reasonable service to the public, there is another, slightly cynical perhaps, viewpoint. For the past two decades the police service in England and Wales has been encouraged to engage with communities and work together in partnership with others, including communities, and to view communities as customers of their service. We live in a consumerist society whereby people expect to be treated and dealt with as customers, and provided with all the courtesies attached to that title (Halpren, 2010; Rogers \& Martin, 2007). Unfortunately, the image of the police in general has not always led to that expectation being delivered. Major incidents such as the original enquiry into the murder of Stephen Lawrence, along with other high profile cases, such as the Stockwell shooting, in addition to complaints regarding deaths in custody, the increasing number of incivility complaints being recorded by the IPCC year on year and high profile enquiries such as the Leveson enquiry impact upon the public perception of accountability, transparency and decision making of senior and other police officers. Sergeant (2008) consolidated much of the concerns regarding the relationship between police and public and came to the conclusion that there is a huge gap between how the public want to be policed and how the police wanted to police the public. Indeed this has been reinforced recently by an article in the Guardian newspaper entitled 'Britain's police are at war with the Public' which suggests that lack of accountability and understanding of community has led to a chasm opening up between the police and the public they serve (Westmarland, 2010) . It therefore could be argued that because there has been a lack of momentum within the police organisation to change quickly enough, the opportunity has arisen to ensure that this change will now be forced through on the back of the economic framework.

\section{Discussion and Conclusion}

The demands on policing in the UK are considerable, with police officers being asked to carry out a plethora of different roles (Benson \& Zimmerman, 2010; Shilson, 2011). Organisational restructuring and change will continue to be fundamental within police service. The police service, its senior officers/ executives, each individual officer and civilian employee will need to reflect on some of the implications of outsourcing and payment by results as they continue to build a professional service, revolutionising the way it delivers its services to its customers whilst finding new and pioneering ways to remain productive and fit for purpose. Messages from Government and agencies such as HMIC, The Audit Commission and others over the past few years appear to suggest that the police organisation will be re-configured dramatically, or to use term prevalent in some areas of police literature, 'architecturally restructured'. Given the way in which public expenditure is likely to be tightly controlled in the future, and the introduction of commissioners, who may, in part at least, be politically motivated and aware, it seems likely that payment by results will be adopted in some format for the future delivery of policing services in this country. In times of austerity, public bodies are facing the problems associated with maintaining quality service delivery whilst facing large budgetary cutbacks. How organisations are to maintain this expected service delivery to the public whilst adjusting their finances and restructuring themselves is highly problematic. For those engaged in the study of the police in England and Wales the step to outsourcing does not really come as a surprise (Reiner, 2010; Newburn, 2007). Whilst initially the scale of the implementation seems overly large, it seems on the face of it a logical and rational step as the police struggle to maintain their services in tremendous economic constraints. There is of course a certain amount of precedence for this type of provision anyway, and in the main existing provision seems to work reasonably well. Resistance to change is quite natural, but once the benefits of change are seen, generally the situation is accepted and the work continues. Witness the furore about the introduction of community support officers several years ago, for 
example. However, whilst important in its own right, in general, outsourcing should not be the main thrust of the debate. That should revolve around the important area of accountability. As Punch (2009) says, there are three reasons why we should believe in and support our model of policing- accountability, accountability, and more accountability. By its very nature, policing implies a power relationship between those policed and those who police. It is therefore important that those who police, in whatever form, and whether public or private, in-sourced or outsourced, should have the highest level of legal accountability attached to them. Whatever the outcome of the current debate on change in the police in this country, one thing is for certain. The way in which the police deliver their services will dramatically change, and managing public expectations regarding the service provided by the police will need to be carefully thought through.

\section{References}

Audit Commission. (2010). Sustaining Value for Money in the Police Service. London, Audit Commission.

Audit Commission. (2011). Introducing Payments by Results. London, Audit Commission.

Audit Commission. (2012a). Local Payments by Results. London, Audit Commission.

Audit Commission. (2012b). Payments by Results Data Assurance Framework 2012/13: Guidance for Commissioners and their Providers. London, Audit Commission.

Benson, B., \& Zimmerman, P. (2010). Handbook of the Economics of Crime. Cheltenham, Edward Elgar Publishing Limited.

Blair, I. (2012). The Police: a Chance to Modernise. Retrieved February 4, 2012, from $\mathrm{http} / / / \mathrm{www}$.guardian.co.uk/commentisfree/2012/mar/04/chance-to-modernise-police-force?intcmp=239

Brogden, M., \& Ellison, G. (2012). Policing in an Age of Austerity: a Postcolonial Perspective. Oxford, Routledge.

Bryett, K., \& Lewis, C. (1994). Un-Peeling Tradition: Contemporary Policing. Melbourne, Macmillan Educations Australia Ltd.

Button, M. (2002). Private Policing. Cullompton, Willan Publishing.

Cabinet Office. (2012). Open Public Services. London, Cabinet Office.

Davis, A. (2010) Living with Cuts to Public Services: How Can we Get More for Less. Journal of Public Health, 32(3), 310-311. http://dx.doi.org/10.1093/pubmed/fdq091

Dölling, D. (1993). Community Policing: Comparative Aspects of Community Policing Orientated Police Work. Reiden, Germany, Felix-Varlag.

Erridge, A., Fee, R., \& Mcllroy, J. (2001) Best Practice Procurement: Public and Private Perspectives. Hampshire, Gower Publishing Limited.

Flanagan, R. (2008). Her Majesties Inspectorate for the Constabulary: Serving Communities and Individuals. London, HMIC Central Office of Information.

Frost, B., \& Manning, P. (1999). The Privatization of Policing: Two Views. Washington, Georgetown University Press.

Garland, D. (2001). The Culture of Control. Oxford, Oxford University Press.

Gravelle, J., \& Rogers, C. (2010). The Economy of Policing: The Impact of the Volunteer. Policing: A Journal of Policy and Practice, 4(1), 56-63.

Gravelle, J., \& Rogers, C. (2011). Commissioning Accountability: Change to Governance and the Police. The Police Journal, 84(4), 320-328.

Halpern, D. (2007). Social Capital, Cambridge, Polity Press.

Halpern, D. (2010). The Hidden Wealth of Nations. Cambridge, Polity Press.

Her Majesty's Inspectorate of Constabulary. (2010). Valuing the Police: Policing in an Age of Austerity. London, HMIC Central Office of Information.

Home Affairs Select Committee. (2010). Policing: Police and Crime Commissioners - Second Report of Session 2010/11. London, The Stationery Office.

Home Office. (2008). From the Neighbourhood to the National: Policing our Communities Together. London, The Stationery Office. 
Home Office. (2010a). Policing in the 21st Century: Reconnecting Police and the People. London, The Stationery Office.

Home Office. (2010b). Policing: Police and Crime Commissioners, London, The Stationery Office.

Home Office. (2010c). Police and Crime Commissioners: Impact Assessment, London, The Stationery Office.

Home Office. (2010d). Reducing Demand, Restricting Supply, Building Recovery: Supporting People to Live a Drug Free Life. London, HMSO.

Hughes, G. (2007). The Politics of Crime and Community. Basingstoke, Palgrave-Macmillan.

Hunter, I., \& Saunders, J. (2007). Human Resources Outsourcing: Solutions, Suppliers, Key Processes and the Current Market. Hampshire, Gower Publishing Limited.

Ianni, E., \& Ianni, F. (1983). Two Cultures of Policing: Street Cop Management Cop. United States, Transition Publishers.

Jones, T., \& Newburn, T. (2006). Plural Policing: a Comparative Perspective. Abingdon, Routledge.

Kendell, D. (2011). Sociology in Our Times. Belmont, Wadsworth Learning.

Klockars, C. (1985). The Idea of Police. London, Sage.

Loveday, B. (1993). The Local Accountability of Policing in England and Wales: Future Prospects in Accountable Policing: Effectiveness Empowerment and Equity. In R. Reiner, \& S. Spencer (Eds.), Institute for Public Policy Research (pp. 55-80). London. http://dx.doi.org/vathek.org/doi/abs/10.1350/ijps.2005.7.3.197

Lowndes, V., \& Pratchett, L. (2012). Local Governance under the Coalition Government Austerity, Localism and the 'Big Society'. Local Government Studies, 38(1), 21-40. http://dx.doi.org/10.1080/03003930.2011.642949

Markham, G., \& Punch, M. (2007). Embracing Accountability: The Way Forward - Part 2. Policing: A Journal of Policy and Practice, 4(1), 485-495.

Maynard, A. (2012). The Powers and Pitfalls of Payment for Performance. Health Economics, 21, 2-12. http://dx.doi.org/10.1002/hec. 1810

Mcivor, R. (2005). The Outsourcing Process: Strategies for Evaluating and Management. Cambridge, Cambridge University Press. http://dx.doi.org/10.1017/CBO9780511543425

National Audit Office. (2008) The Independent Police Complaints Commission. London, National Audit Office 2008.

Newburn, T. (2007). Handbook of Policing. Cullompton, Willan Publishing.

Neyroud, P. (2010). Protecting the Front Line: The Recessionary Dilemma. Policing: a Journal of Policy and Practice, 4(1), 1-3.

Punch, M. (2011). Shoot to Kill. The Policy Press, Bristol.

Reiner, R. (2010). The Politics of the Police (4th ed.). London, Oxford University Press.

Rogers, C., \& Gravelle, J. (2012). UK Policing and Change: Reflections for Policing Worldwide. Review of European Studies, 4(1), 42-52. http://dx.doi.org/10.5539/res.v4n1p42

Rogers, C., \& Lewis, R. (2007). Introduction to Police Work, Cullompton, Willan Publishing.

Rogers, C., \& Martin, H. (2007). Managing Customer Demand. Policing Today, 14(3), 33-34.

Savage, S. (2007). Police Reform: Forces for Change. Oxford, Oxford University Press.

Sergeant, H. (2008). The Public and The Police. Civitas, London.

Shilson, T. (2011). Black Box: A Qualitative Method for Improving Public Confidence in Policing Through Micro-Analysing Service Delivery. Policing: A Journal of Policy and Practice, 5(2), 125-131.

Skinns, L. (2009). I'm a detainee get me Out of Here': Predictors of Access to Custodial Legal Advice in Public and Privatized Police Custody Areas. British Journal of Criminology, 49(3), 399-417. http://dx.doi.org/10.1093/bjc/azp002

Tarvis, A., \& Jowit, J. (2012). Police Privatisation Plans Defended by Senior Officers. Retrieved February 4, 2012, from http://www.guardian.co.uk/uk/2012/mar/04/police-privatisation-plans-defend-acpo?intcmp=239 
Travis, A. (2012). Police Privatisation Must be Stopped, says Lord Prescott. Retrieved February 4, 2012, from $\mathrm{http}: / / w w w . g u a r d i a n . c o . u k / \mathrm{uk} / 2012 / \mathrm{mar} / 05 /$ police-privatisation-stopped-lord-prescott

Travis, A., \& Williams, Z. (2012). Revealed: Government Plans for Police Privatisation. Retrieved February 4, 2012 , http://www.guardian.co.uk/uk/2012/mar/02/police-privatisation-security-firms-crime? intcmp=239

Westmarland, L. (2010). Dodgy Customers: Can the Police Ever Trust the Public?. Policing: a Journal of Policy and Practice, 1(3), 291-297.

Whitfield, D. (2012). The Mutation of Privatisation: a Critical Assessment of New Community and Individual Rights. European Service Strategy Unit, 5(1), 1-31.

Williamson, T. (2008). The Handbook of Knowledge Based Policing. Chichester, Wiley. http://dx.doi.org/10.1002/9780470773215

Winsor, T. (2012). Independent Review of Police Officer and Staff Remuneration and Conditions: Part 2. London, The Stationery Office. 